Chirurgia (2019) 114: 550-563

No. 5, September - October

Copyright $@$ Celsius

http://dx.doi.org/10.21614/chirurgia.114.5.550

\title{
Pancreatic Neuroendocrine Tumour in Pregnancy - Diagnosis and Treatment Management
}

\section{Dragoș Predescu}

General and Esophageal Surgery Department, Center of Excellence in Esophageal Surgery, Sf. Maria Clinical Hospital, Bucharest, Romania

Corresponding author:

Dragoș Predescu MD

General and Esophageal Surgery

Department, Center of Excellence

in Esophageal Surgery, Sf. Maria

Clinical Hospital, Bucharest

37-39 Bdul lon Mihalache, sector 1

Bucharest, Romania

E-mail: drpredescu@yahoo.com

\section{Abbreviations:}

PNET - Pancreatic Neuroendocrine

Tumours;

GET - Gastroenterohepatic;

VIP - Vasoactive Intestinal Polypeptide;

EUS - Endoscopic Ultrasound;

EGD - Esophagogastroduodenoscopy;

CT - Computed Tomography;

MRI - Magnetic Resonance Imaging;

MEN - Multiple Endocrine Neoplasia.

\section{Rezumat \\ Neoplazia neuroendocrină pancreatică în sarcină și managementul de diagnostic și tratament}

Cazurile de cancere digestive diagnosticate în timpul sarcinii sunt rare, raportarea lor fiind sporadică. Deplasarea gravidității spre intervalul de vârstă '30-39 de ani (şi deloc excepțional 40-49 ani) ar putea explica suprapunerea din ce în ce mai frecventă a cancerelor şi sarcina. Tumorile pancreatice de tip NET (PNET) au origine în țesutul endocrin insular, fiind entități extrem de rare, având caracteristic un comportament de dezvoltare neoplazică lent, puțin agresive, cu capacitatea de a secreta şi înmagazina diferite peptide şi neuroamine. Din grupa mare a tumorilor de tip NET, cca $70 \%$ sunt localizate gastro-entero-hepatic (GET) şi reprezintă mai puțin de $2 \%$ din tumorile tubului digestiv. Incidența PNET este extrem de redusă cca 1/100.000. În literatură, asocierea sarcină-PNET este exceptională, fiind raportate până la acest moment 39 astfel de cazuri. Cea mai frecventă PNET raportată la gravide este insulinomul, pînă în 2012 fiind publicate 27 de cazuri la nivel global, cu punct de dezvoltare în celulele B-pancreatice, dintr-un total de 39 cazuri de PNET descrise. Diagnosticul la gravide este îngreunat în prima parte a sarcinii deoarece, din punct de vedere fiziologic, în această perioadă glucoza are tendința să aibă nivel scăzut, consecință a secreției crescute de insulină şi a sensibilității la insulină, probabil ca efect al creşterii nivelului de estrogeni. De asemenea, şi alte semne care ar putea sugera prezența unei "probleme", cum ar fi astenie neexplicată, vărsături, hipotensiune, episoade reduse de hipoglicemie, sunt relativ comune în primul trimestru de sarcină. Dificilă este şi evaluarea paraclinică a acestor paciente, un indicator important al oportunitătii unei 
investigații sau alteia revenind trimestrului de graviditate. Precauția legată de "compromiterea" fetală în indicarea unei explorări invazive (imagistice, endoscopice, etc) întârzie de asemenea diagnosticul. Caracterul puțin agresiv, mai de curând cu potențial benign face ca prognosticul insulinoamelor să fie în general unul favorabil iar posibilitățile terapeutice uşor de administrat şi controlat la gravide. Tratamentul medical se adresează pacientelor atunci când există diagnostic pozitiv dar nu putut identifica topografia insulinomului, când simptomatologia este uşor controlată prin terapie conservatoare până când se obține o vârstă convenabilă a fătului fie imediat postpartum, la gravidele care refuză intervenția chirurgicală, fie în stadiul metastatic al insulinomului malign. Tratamentul chirurgical rămâne cu adevărat singura modalitate de rezolvare terapeutică dar, cel mai adesea, sub forma unei chirurgii programate, de regulă post-partum, sau dacă situația "forțează" indicația, cât mai târziu după o vârstă fetală convenabilă (după 28 săptămâni).

Cuvinte cheie: neoplazia neuroendocrinã pancreaticã, sarcinã, managementul de diagnostic şi tratament

\begin{abstract}
Digestive cancers diagnosed during pregnancy are rare and are sporadically reported. The shift of pregnancy towards the age interval of 30-39 years old (and even 40-49 years old) could explain the more and more frequent superposition of pregnancy and cancer. Pancreatic Neuroendocrine Tumours (PNET) originate in the insular endocrine tissue and are extremely rare; they have a slow, less aggressive neoplastic development, with the capacity of secreting and storing different peptides and neuroamines. From the large group of NET tumours, approximately $70 \%$ have a gastroenterohepatic (GET) localisation and represent less than $2 \%$ of the digestive tract tumours. PNET incidence is extremely reduced, of approximately 1/100.000. The association of pregnancy and PNET in literature is exceptional until now only 39 cases were reported. The most frequent PNET in pregnant patients is the insulinoma with the starting point in pancreatic B-cells, with 27 out of 39 PNET worldwide reported cases until 2012. Establishing a diagnosis in pregnant patients is difficult in the first period of pregnancy because physiologically, the glucose tends to be low. This may be a consequence of the increased secretion of insulin and sensibility to insulin, probably as an effect of increased oestrogen levels. Furthermore, there are other signs which could suggest the existence of a "problem", which are relatively common during the first trimester of pregnancy: unexplained fatigue, vomiting, hypotension, rare episodes of hypoglycaemia. Performing paraclinical tests on these patients is difficult; an essential indicator of the opportunity for the investigation is the pregnancy trimester. The precaution about a foetal injury when indicating an invasive exploration (imaging, endoscopy, etc.) delays the diagnosis. The insulinomas have a rather benign potential than an aggressive nature, and their prognosis is usually favourable, with therapeutic possibilities easy to administrate and control in pregnant patients. Medical treatment is used in patients when there is a positive diagnosis but the topography of the insulinoma was not identified, when the symptomatology is easy to control through conserving therapy until the foetus is mature enough or immediately after birth, in pregnant patients who refuse the surgical procedure, or in the case of metastasis of malignant insulinoma. Surgical treatment indeed remains the only therapeutic method, but most often it is scheduled usually after birth, or if the situation requires, as late as possible after the foetus has a convenient age (after 28 weeks).
\end{abstract}

Key words: pancreatic neuroendocrine tumour (PNET), pregnancy, diagnosis and treatment management 


\section{Introduction}

Digestive cancers diagnosed during pregnancy are rare and are sporadically reported. The shift of pregnancy towards the age interval of 30-39 years old (and even 40-49 years old) could explain the more and more frequent superposition of pregnancy and cancer. Various population studies (1-5) observe an explosive increase of some digestive neoplasms in the last 3-4 decades, especially when studying the 15 - 49 years old group age, the fertile period of women. Similar to breast cancer, digestive cancers in pregnancy are the cancers diagnosed during pregnancy and in the first year postpartum. Of the many gastrointestinal sites affected by neoplasia, the most frequent affected seem to be the stomach, the rectum and the colon; liver and pancreas cancers have been exceptionally reported. The difficulty of establishing the diagnosis of digestive cancer during pregnancy is caused by the existence of signs and symptoms which can be attributed to pregnancy, due to the common abdominal site of the pregnant uterus and visceral neoplasm. It is challenging to perform paraclinical tests on these patients, an essential indicator of the opportunity for investigation being the pregnancy trimester. The precaution about foetal injury when indicating an invasive exploration (imaging, endoscopy, etc.) delays the diagnosis.

The diagnosis and treatment protocols for patients who are not pregnant are different than the ones for pregnant patients; most often, a multidisciplinary approach will define a correct, equilibrated and optimal treatment plan. This approach involves the association of a medical oncologist, a gynaecologist, a gastroenterologist, a surgeon, a paediatrician, a neonatologist and an oncology psychologist, together with the patient and her family.

\section{Pancreatic Neuroendocrine Tumours}

Pancreatic Neuroendocrine Tumours (PNET) originate in the insular endocrine tissue and are extremely rare; they have a slow, less aggressive neoplastic development, with the capacity of secreting and storing different peptides and neuroamines (6). From the large group of NET tumours, approximately $70 \%$ have a gastroenterohepatic (GET) localisation and represent less than $2 \%$ of the digestive tract tumours. PNET incidence is hugely reduced, of approximately 1/100.000 (7-9). The association of pregnancy and PNET in the literature (10) is exceptional; until now, only 39 cases were reported.

Mainly, from the operational point of view, PNET are divided into two groups: 1) PNET associated with the secretion of biologically active substances with the emergence of specific syndromes; 2) non-functional PNET (NF-PNET). The distinction between these two groups is vital for PNET diagnosis and treatment $(7-9,11)$.

From the group of functional PNET the most frequent tumours are: insulinoma, gastrinoma, VIPoma, somatostatinoma, glucagonoma, GH-releasing factor secreting (GRFomas), and less common PNET groups: secreting ACHT (ACTHoma) with the emergence of Cushing syndrome, PNET associated with carcinoid syndrome or hypercalcemia, or the rare ectopic PNET secreting luteinizing hormone, renin or erythropoietin.

NF-PNET forms are twice as frequent than functional PNETs.

The emergence of PNET can sporadically appear in the context of hereditary genetic disorders, approximately $80-100 \%$ of PNET appear in patients with MEN I, $10-17 \%$ in patients with Hippel-Lindau syndrome and up to $10 \%$ in patients with von Recklinghausen disease (neurofibromatosis type $1 \mathrm{NF}-1$ ), all of them being autosomal dominant transmission diseases; MEN I is the most frequent cause, being the consequence of a mutation in $11 \mathrm{q} 13$ chromosome $(13,14)$. The patients with MEN I develop hyperplasia of tumour growth with various sites in endocrine and non-endocrine tissues (parathyroid adenomas, pituitary adenomas, carcinoid tumours, thyroid adenomas, skin tumours, adrenal gland tumours, etc.). As a consequence, genetic 
analysis could be necessary for a complete diagnosis (15).

The most frequent PNET in pregnant patients is the insulinoma with the starting point in pancreatic B-cells, with 27 out of 39 PNET worldwide reported cases until 2012 $(10,16)$. The vast majority $(!)$ are described in the first trimester of pregnancy, but there were cases at the end of pregnancy ( 1 case) or immediately postpartum (4 cases). Other PNET tumours are more rarely described, especially in pregnant patients: gastrinoma, VIPoma, somatostatinoma, glucagonoma, etc. (in the order of frequency). The different degrees of tumour aggressiveness, pregnancy in different evolution phases, the association of multiple MEN I specific pathologies, inabilities to establish the diagnosis make each case a difficult to manage entity, both from the diagnostic and therapeutic point of view (17-20) (Table 1).

The prevalence of insulinoma in general population is of $1 / 250.000$, the essential characteristic being an insulin-secreting tumour (C-peptide), with symptomatic hypoglycaemia (the Whipple triad: low level of blood glucose, neuroglycopenia - confusion, conscience alteration, the enhancement of manifestations when administrating glycemic treatment).

In our country, the largest statistics is the one of professor I. Juvara, 55 observations until 1984, to which are added 16 cases published by Tr. Pătraşcu from the same medical clinic, from 1985 to $2002(21,22)$. The same author (22) estimates that there are under 3000 cases published worldwide, and there are other Romanian authors who published such cases, like for example A. Popovici (23-25), but neither of them was simultaneous with pregnancy. The majority of insulinomas have a primary pancreatic site (98\%), but there are also ectopic insulinomas in the duodenum, jejunum, ileum, lung (21). Usually there are small tumours (5\% under $0.5 \mathrm{~cm}, 34 \%$ between $0.5-1 \mathrm{~cm}, 53 \%$ between $1-5 \mathrm{~cm}$ and only $8 \%$ over $5 \mathrm{~cm}$ ), in the head (20 $-30 \%)$ or tail $(20 \%)$ of the pancreas $(26)$. In $3,5 \%$ of cases (27), the tumours are multifocal.

\section{Clinical Examination and Symptomatology}

During a hypoglycaemic crisis, the following symptoms may appear - memory disorders, confusion, behavioural changes (petulance, agitation, drowsiness), mental and physical fatigue, sensory perception disorders (hypoacusis, eye accommodation disorders), paraesthesia, amnesia. The coma is initially superficial, but as the hypoglycaemia is accentuated, it becomes profound, and convulsions may appear $(21,26,27)$. Attention! Approximately $40 \%$ of the patients who

Table 1. Signs, symptoms and incidence of functional PNET

\begin{tabular}{lllc}
\hline Tumour type & $\begin{array}{l}\text { Hormone / } \\
\text { secreted peptide }\end{array}$ & Signs and symptoms & $\begin{array}{c}\text { Statistic incidence out } \\
\text { of functional PNET }\end{array}$ \\
\hline Insulinoma & Insulin & Hypoglycaemia episodes & $35-40 \%$ \\
\hline $\begin{array}{l}\text { Gastrinoma } \\
\text { (Zollinger-Ellison syndrome) }\end{array}$ & Gastrin & Refractory peptic ulcer & $16-30 \%$ \\
\hline Glucagonoma & Giarrhoea & Diabetes \\
& & Venous thromboembolism & $<10 \%$ \\
& & Dermatitis \& Necrolytic erythema & \\
VIPoma & Diarrhoea & $<10 \%$ \\
& Vasoactive intestinal & Watery diarrhoea & $<5 \%$ \\
Somatostatinoma & polypeptide (VIP) & Hypokalaemia & \\
& Somatostatin & Diabetes & \\
& & Steatorrhea & \\
& & $\downarrow$ G & \\
& & Cholelithiasis & \\
& &
\end{tabular}


arrive at the hospital are in a coma or have suffered a loss of consciousness. Establishing a diagnosis in pregnant patients is difficult in the first period of pregnancy because physiologically, the glucose tends to be low. This situation may be a consequence of the increased secretion of insulin and sensibility to insulin, probably as an effect of increased oestrogen levels (28).

Furthermore, there are other signs which could suggest the existence of a "problem", which are relatively common during the first trimester of pregnancy: unexplained fatigue, vomiting, hypotension, rare episodes of hypoglycaemia. The alarm raised by a prolonged or exaggerated hyperemesis is due to the synergistic action of acidosis, respectively of persistent hypoglycaemia. The metabolic status of each pregnant patient is essential; obesity gives a certain protection against hypoglycaemia.

In the case of advanced pregnancies, the rarity of the diagnosis in this stage (one single reported case) (29) is explained by the increase of resistance to insulin, which leads to the absence of / minor episodes of hypoglycaemia. In the postpartum period, once the sensibility to insulin is restored, these tumours may be discovered due to the appearance of specific symptomatology.

The interesting fact in patients with insulinoma is that the hypoglycaemic crisis evolves gradually, with initial sensorial and movement disorders, then with the narrowing of consciousness to coma and seizures. The clinical examination is influenced by the way glycopenia appears and its duration: if the drop is rapid, an adrenergic picture will emerge, if it is a slight decrease neuropsychological signs appear. Note that once the pregnancy period is over, the neurological manifestations caused by glycopenia can be considered to be psychical postpartum disorders (!) (30).

Some patients recognise the beginning of a glycopenic crisis, and they manage to avoid it by ingesting carbohydrates. When evolving, especially in case of malignancy, the crises worsen, become more complex, subintrant. There is no parallel between the severity of hypoglycaemia and the severity of symptomatology, the sensibility threshold being characteristic to each patient (21).

Some physiological information is necessary. In the first trimester of pregnancy, the level of blood glucose is generally low due to an increase of insulin and cellular sensibility to insulin, as a side effect of oestrogen increase (28). Once the pregnancy advances, a new series of hormonal changes alter the maternal glucose metabolism, on the one hand by altering pancreatic 6 -cells function, and on the other hand by increasing the peripheral cellular resistance to insulin. It appears that among the placental hormones involved, the placental growth hormone is the most important. It has an effect of peripheral cellular resistance to insulin due to an overexpression of $\mathrm{p} 85 \mathrm{a}$ subunit, having as a consequence the binding to IRS-1, the reduction of PI 3-kinase activity and insulin signalling, and the translocation of GLUT4 to the plasma membrane (31). The same effect is due to the presence of tumour necrosis factor (TNF secreted by the placenta) and circulating leptins (32).

Another hormone involved, the placental lactogenic hormone, stimulates the increase of pancreatic B-cells and insulin secretion.

\section{Paraclinical Diagnosis}

The diagnosis is suggested by (117): glycaemia < $40 \mathrm{mg} / \mathrm{dL}$ concurrently with serum insulin $>3 \mu \mathrm{U} / \mathrm{mL}$, C-peptide level $200>\mathrm{pmol} / \mathrm{L}$, proinsulin value $>5 \mathrm{pmol} / \mathrm{L}, \mathrm{A}$-hydroxybutyrate $<2.7 \mathrm{mmol} / \mathrm{l}$, the absence of sulfonylureas in plasma or urine and confirmed by the 72 hours fasting plasma glucose test.

A diagnostic option would be alimentary abstinence for 48-72 hours, under medical surveillance, by taking regular blood samples at 6 hours. When glucose is $<60 \mathrm{mg} / \mathrm{dL}$, blood glucose is collected hourly. The assessment continues until the patient begins to suffer from hypoglycaemia $(<45 \mathrm{mg} / \mathrm{dL})$, with or without neurological symptomatology, until the 72 hours is accomplished. The diagnosis becomes apparent with the sampling / the 
result of plasma insulin $\mathrm{R} 6 \mathrm{mU} / \mathrm{mL}$ (RIA) or $\mathrm{R} 3 \mathrm{mU} / \mathrm{mL}$ (ultrasensitive method), $\mathrm{C}$ peptide $\mathrm{R} 0.2 \mathrm{nmol} / \mathrm{L}$, negative sulphonylurea and negative insulin antibodies (33).

The suggestion of a malignancy, evident in the presence of metastases, is brought by severe symptomatology, associating an insulin level and C-Peptides 2-3 times higher than in the benign cases. A supplementary proof is the fast positive result of the $72 \mathrm{~h}$ fasting test $(34,35)$.

The standard abdominal ultrasound is not an infallible method, having a limited diagnostic role, especially late in pregnancy, due to a low diagnostic sensibility; it has the potential for identifying hepatic metastases. Thus, the diagnosis needs to be completed with other investigations. Generally, the insulinoma is a small tumour $<2 \mathrm{~cm}$, explaining the difficulty of establishing a diagnosis using imaging techniques. The endoscopic ultrasound (EUS) is an interesting possibility, with a redoutable diagnostic value, having a sensibility of around $93 \%$, a specificity of approximatively $95 \%$ and an accuracy of $93 \%$, especially if it can be performed in guiding histologic punctures (the rate of unsatisfactory bioptic samples ranges from 9 to $20 \%)(36-40)$.

The EUS diagnosis has higher rates of success than CT or MRI but it has a series of limitations due to pregnancy, and the risks of this method cannot be overlooked: placental abruption as a consequence of lumenal instillation and pressure on the abdomen, diverse foetal lesions secondary to hypotension or maternal hypoxia during explorations which use oversedation, teratogenesis caused by administrated medication, etc. Here are some mandatory rules: fasting for 6-7 hours before the investigation, left lateral decubitus position of the mother during endoscopy for optimal placental perfusion, nasogastric tube, oxygen administration to the mother and pulse oximetry, blood pressure check, foetal heart rate monitoring, peripheral venous line $(41,42)$.

Teratogenesis or abortion risks are low, usually encountered in the first trimester. The medication administered has to be limited to the maximum (see endoscopy exploration in colorectal cancer). Generally, the studies (43-45) performed in pregnant patients who underwent an esophagogastroduodenoscopy (EGD) for diverse indications have not confirmed any risks for the foetus, over 95\% having healthy newborn children and a foetal status with no complications.

The ultrasound becomes redoutable in the time of surgery when the identification of a lesion is facilitated as to the simple palpation. Intraoperative palpation, combined with intraoperative ultrasound is over $95 \%$ sensitive (39).

If the evolution is severe, with the impossibility to establish a diagnosis through other methods which could lead to a therapeutic approach, radiological investigations are performed. Imaging assessment (CT, MRI, arteriography, radionuclide imaging) used for identifying the tumour site/staging/ complications is most of the time-limited by the X-ray irradiation of the foetus and by the inefficiency of explorations, the tumours having small dimensions, under $2 \mathrm{~cm}$. In 12 cases (!) out of the 27 reported worldwide, the diagnosis was established only during laparotomy; the imaging pre-operative assessments were not efficient.

\section{Computed Tomography (CT)}

Even if essential for topography and staging, the $\mathrm{CT}$ remains the subject of numerous debates. It would be better to use other technique every time this method can be avoided. If the $\mathrm{CT}$ is crucial for establishing a diagnosis, in his quality of the therapeutic guide, the physician should not hesitate to use it, since the mother's life prevails. What can CT bring to the evaluation of neoplasia during pregnancy? Firstly, the method allows the identification of the tumour and its topography and permits a three-dimensional assessment of the relation between the tumour and the adjacent structures. Secondly, it will enable assessing the histopathological nature (malignancy/benign) and staging. CT has a $73 \%$ specificity and a $96 \%$ sensibility for PNET diagnosis (46), the arterial phase 
having the highest success rate in establishing the diagnosis. The overvaluation of the $\mathrm{T}$ index is the most common problem. The dimensional limits of the method are around 1 $\mathrm{cm}$. This is why tracing adenopathies/nodes ( $\mathrm{N}$ index) remains a problem when they are $<1 \mathrm{~cm}$. Thus, the specificity in $\mathrm{N}$ detection is $45 \%$ (!). The essential role of CT is the assessment of $\mathrm{M}$ index, the identification of liver metastases have an $85 \%$ accuracy and a $97 \%$ specificity. The data overlaps with the one obtained through MRI (47).

Over the last 40 years, CT was contraindicated in pregnant patients because of the teratogenetic and carcinogenetic effects on the foetus. The introduction of spiral CT scan diminished the irradiation drastically during exploration, an entire segment (for example, abdomen or pelvis) being scanned in 17-19 seconds for selected fields at $1.25 \mathrm{~mm}$. For this reason, the CT method was re-evaluated when using it in pregnant patients.

The teratogenetic effect of $\mathrm{CT}$ radiations has a non-cumulative (non-stochastic) nature. The period the most susceptible to the impact of CT radiation corresponds to the period of organogenesis, especially in the $2-15$ weeks of pregnancy. The teratogenetic complications include $(48,49)$ : mental retardation, growth disorders, microcephaly, microphthalmia, behavioural disorders, and cataract. The threshold dose (50) under which teratogenetic effects do not appear is not known, but it seems to be of 5-15 cGy. During a spiral CT, the dose administrated to the foetus is variable (51-55), depending on a series of elements (for example the examination parameters). It can be of 2.9 $4.4 \mathrm{cGy}$, the radiation dose being way under the critical threshold, which causes congenital malformation (56).

The carcinogenetic effect during a CT investigation is a stochastic one, without any threshold dose. Furthermore, there is a connection between the moment of exposure to radiation during pregnancy and the risk of carcinogenesis. The smaller the pregnancy, the higher the risk $(57,58)$. It is considered that at an average dose used for a CT (2-5 cGy) the risk of cancer during childhood doubles.
Anyway, the value is low, and the recommendations of the American College of Obstetricians and Gynecologists are significant: "very low carcinogenetic risk, abortion not recommended" $(54,55,59,60)$.

Another problem raised is the use of contrast agents. There were no teratogenetic / mutation effects in in vivo studies $(61,62)$. Using iodinated contrast was thought to have a potential in developing hypothyroidism to the foetus $(63,64)$, but these reluctances were eliminated through newer studies $(65,66)$, which have not found any side effect of the child's thyroid function after the exposure to these substances during the foetal period.

Magnetic resonance imaging (MRI) is the option used in the case of pregnant patients instead of CT. It provides information and complex topographic relations (three dimensional), with $93 \%$ sensibility and $88 \%$ specificity (46). Regarding distance staging indices ( $\mathrm{N}$ and $\mathrm{M})$, the method has limitations similar to CT, but with higher costs. The references one has to observe are the same as for CT. The major disadvantage is the presence of artefacts, induced by secondary enteral peristaltic contractions and respiratory movements, producing image degradation (scanning lasts 5-10 minutes) (67).

There are a series of discussions regarding the safety of the method in pregnant patients, because of possible teratogenetic effects of magnetic fields and an eventual acoustic trauma of the foetus. The in vivo studies on animals of Heinrichs and collaborators (68) and Tyndall (69) showed the presence of malformations as a result to the exposure to magnetic fields (for example eye malformations), the death of embryos or anomalies when the exposure took place during organogenesis (70). As a consequence, even if similar effects were not proven in humans, the National Radiological Protection Board from Great Britain (71) recommends: "it is prudent to avoid MRI in pregnant patients in the first three months of pregnancy".

The possible acoustic effects induced to the foetus by the high level of sound during MRI are rather theoretical, without really being a 
clear threat $(72,73)$, and as to the contrast medium, no teratogenetic effects were reported $(74,75)$

Therefore, MRI will be performed in the first trimester of pregnancy, especially for maternal and less for foetal indications. This method is preferable to any other investigation method which uses ionising radiations (76).

Concerning other diagnostic methods like nuclear techniques (for example PET-CT), they are not usually used for evaluating pregnant women, and there are no studies which could prove their value, mainly due to a weak metabolic activity of PNET to $18 \mathrm{~F}$-deoxyglucose. Newer studies which use $11 \mathrm{C}-5$-hydroxy-tryptophan (11C-5-HTP) or $68 \mathrm{Ga}$ somatostatin analogues seem to be very promising (77).

Extrapolating the use of the technique in other tumours of the digestive tract, one can use PET-CT for selected cases, with several specific recommendations (reduction of 18F-FDG dose, using the 3D technology which would allow the decrease of $18 \mathrm{~F}-\mathrm{FDG}$ dose, proper hydration, mitigation of CT voltage, etc.). PET-CT seems to be useful in identifying the tumour site and assessing the degree of invasion in distant sites (metastatic adenopathy, distant metastases). The development of technology allowed that cumulated irradiation doses to the foetus during and after PET-CT be at acceptable levels (1-2 cGy), comparable to or even smaller than the doses administered through spiral CT (78-80).

The versions using radionuclides (Osteoscan scintigraphy - somatostatin receptor) or newer techniques of ligands with affinity to specific receptors can bring information about the tumour site, but unfortunately, they can be used only in the postpartum period because of the harmful foetal effects.

\section{Staging and Prognosis}

Establishing a unitary PNET staging conduct, including insulinomas, was not a useful task. The relatively small number of cases could be an explanation. The main competitors were the ones of AJCC (7th edition) and ENETS
2006 Staging System Definition, a parallel staging which was using the same TNM (tumour-node-metastasis) terminology, but referring to different types and spread of PNET. Initially, AJCC staging was assimilating TNM for exocrine cancer with the one for PNET, while ENETS was proposing a version specific for PNET $(81,82)$. Therefore, TNM submitted by ENETS had the advantage of offering an increased layering of proposed prognosis and treatment, as opposed to AJCC (83-88) (Table 2).

Later, AJCC (8th edition) (89) lined up to the ENETS version and introduced the same criteria for $\mathrm{T}, \mathrm{N}$ and $\mathrm{M}$ indices, including the $\mathrm{G}$ index (histologic grade) which assesses tumour aggressiveness and has evident particularities specific to PNET - mitotic index, respectively Ki67 index.

The prognosis is generally convenient, both for the mother and foetus. Based on impressive statistics of 432 cases, H.Y. Peiper finds $85 \%$ benign lesions and only $15 \%$ malignant lesions.

Malignant insulinomas are rare $(5-15 \%)$, and usually, in these cases, the tumours are $>6 \mathrm{~cm}$. Approximately $5 \%$ of patients already have metastases at the moment of diagnosis, especially liver metastases (47\%) and in the locoregional lymph nodes (approx. 30\%). The association with MEN (Multiple Endocrine Neoplasia) is rare; only $4 \%$ of patients with polyglandular syndromes had an insulinoma associated. The adenomas are benign, and they can be unique or multiple, with various sizes (micro and macroadenomas). Macroscopically they are well-encapsulated pinkyreddish, yellowish or purplish round tumours, with a consistency similar to normal pancreatic parenchyma. Carcinomas do not have macroscopic characteristics which could ensure the differentiation from a benign lesion. A tumour size over $5 \mathrm{~cm}$ and the presence of metastases are macroscopic criteria for a malignancy diagnosis. They have more firm consistency than benign lesions, a pinkish-grey section with central necrosis and a tendency to invade the adjacent pancreatic tissue.

The insulinomas have a rather benign 
Table 2. ENETS versus AJCC7TH edition staging evaluation criteria, defining PNET tumour aggressiveness through the $G$ index (histologic grade) in the updated AJCC (8th edition)

\begin{tabular}{|c|c|c|c|c|c|}
\hline & & \multicolumn{2}{|c|}{ ENETS TNM } & \multicolumn{2}{|c|}{ AJCC TNM } \\
\hline \multirow[t]{4}{*}{ TNM } & $\mathrm{T} 1$ & \multicolumn{2}{|c|}{ Confined to pancreas, $<2 \mathrm{~cm}$} & \multicolumn{2}{|c|}{ Confined to pancreas, $<2 \mathrm{~cm}$} \\
\hline & T2 & \multicolumn{2}{|c|}{ Confined to pancreas, $2-4 \mathrm{~cm}$} & \multicolumn{2}{|c|}{ Confined to pancreas, $>2 \mathrm{~cm}$} \\
\hline & T3 & \multicolumn{2}{|c|}{$\begin{array}{l}\text { Confined to pancreas, }>4 \mathrm{~cm} \text {, } \\
\text { or invasion of duodenal or bile duct }\end{array}$} & \multicolumn{2}{|c|}{$\begin{array}{l}\text { Peripancreatic spread, but without major vascular } \\
\text { invasion (celiac trunk, SMA) }\end{array}$} \\
\hline & T4 & \multicolumn{2}{|c|}{ Invasion of adjacent organs or major vessels } & \multicolumn{2}{|c|}{ Major vascular invasion } \\
\hline \multirow[t]{7}{*}{ Stage } & & I & T1 NO MO & IA & T1 NO MO \\
\hline & & & & $\mathrm{IB}$ & T2 NO MO \\
\hline & & $\| A$ & T2 NO MO & $\| A$ & T3 NO MO \\
\hline & & $\| \mathrm{B}$ & T3 NO MO & IIB & T1-3 N1 M0 \\
\hline & & $\| \mathrm{A}$ & T4 NO MO & III & T4 AnyN M0 \\
\hline & & IIIB & AnyT N1M0 & & \\
\hline & & IV & AnyT AnyN M1 & IV & AnyT AnyN M1 \\
\hline
\end{tabular}

ENETS, European Neuroendocrine Tumor Society; AJCC, American Joint Committee on Cancer; TNM, tumor, node, metastasis; PNETs, pancreatic neuroendocrine tumors; SMA, superior mesenteric artery

\begin{tabular}{ll}
\hline G & G Definition \\
\hline GX & Grade cannot be assessed \\
\hline G1 & Mitotic count (per $10 \mathrm{HPF})^{*}<2$ and Ki-67 index $(\%)^{* *}<3$ \\
G2 & Mitotic count (per $10 \mathrm{HPF})=2-20$ or Ki-67 index $(\%)^{* *}=3-20$ \\
G3 & Mitotic count (per $10 \mathrm{HPF})>20$ or Ki-67 index $(\%)^{* *}>20$ \\
\hline
\end{tabular}

${ }^{\star} 10 \mathrm{HPF}=2 \mathrm{~mm} 2$; at least $50 \mathrm{HPF}$ (at 40x magnification must be evaluated in areas of highest mitotic density in order to adhere to WH0 2010 criteria.

**MIB1 antibody; \% of 500-2,000 tumor cells in areas of highest nuclear labelling.

In cases of disparity between Ki-67 proliferative index and mitotic count, the result that indicates a higher-grade tumor should be selected as the final grade. For example, a mitotic count of 1 per $10 \mathrm{HPF}$ and a Ki-67 of $12 \%$ should be designated as a G2 NET

potential than an aggressive nature, and their prognosis is usually favourable, with therapeutic possibilities easy to administrate and control in pregnant patients. Hypoglycaemia can have a possible effect upon the vitality of the foetus, but the increase of insulin resistance, the presence of placental lactogenic hormone and maintaining a reasonable glycaemia through diet or treatment seem to minimise the impact. The presence of malignancy leads to remarkably different survival rates in general population; at five years postoperative the survival rate ranges between $16 \%$ and $56 \%$, but in pregnant patients, only two cancer cases were reported out of the 27 published, without information about metastatic evolution (91).

\section{Therapeutic Management}

The treatment paradigm changes in the case of pregnancy, because the therapeutic management has to fulfil the interests of both mother and foetus, without affecting one another. The therapeutic protocols are modified regarding both the sequence of used methods and timing and that is why the optimal management requires a multidisciplinary approach involving a medical oncologist, a gynaecologist, a surgeon, an anaesthesiologist, a neonatologist and sometimes surgery in mixed teams gynaecologistsurgeon. The family should not be excluded when decisions are made, and a series of legal, ethical, religious, personal and emotional factors have to be taken into account.

The therapeutic management is relatively convenient considering the less aggressive behaviour of the tumour: maintaining and monitoring reasonable levels of blood glucose through reduced meal portions frequently administrated, glucose perfusions until the foetus is mature enough for birth, followed by 
resectional surgery $(92,93)$.

But the situation can get more complicated than that. The essential criteria for the therapeutic decision are imaging confirmation (or not) (identifying topography), characterisation of tumour behaviour (benign/malignant and eventually the stage), the aggressiveness of symptomatology, how advanced the pregnancy is, the family's (mother's) choice.

Medical treatment is used in patients when there is a positive diagnosis but the topography of the insulinoma was not identified, when the symptomatology is easy to control through conserving therapy until the foetus is mature enough or immediately after birth, in pregnant patients who refuse the surgical procedure, or in the case of metastasis of malignant insulinoma. When the tumour is not identified, conserving therapy is justified, and the surgical procedure is postponed as much as possible. Hence it buys time for the evolution of pregnancy, and on the other hand, over time, the pancreatic tumour will increase, allowing the performing of topographic diagnosis followed by curative resection.

The hypoglycaemia crises are controlled through a combination of dietary regimen and intravenous administration of glucose. Repeated meals at 2-3 hours, including at night, with food allowing a slow-release of glucose (bread, pasta, potatoes, rice); "aggressive" concentrated sweets must be avoided. When prodromes, which signal the onset of a hypoglycaemia crisis, appear the intake of sweets is necessary, for example, fruit juice. In addition to diet / perfusions we can take into account the administration of beta-blockers (propranolol), octreotide (controls hypoglycaemia in over $50 \%$ of cases and controls the efficacy of Octreoscan therapy), streptozotocin (toxic effects on beta insular cells), Diazoxide (50 $1500 \mathrm{mg} /$ day) with an effect of hyperglycaemia as a result of insulin issuing and glycogenolysis stimulation. Diazoxide is the first line of medical treatment. In the case of inefficiency, the second line of therapy opens Somatostatin analogues. The B security clearance level of FDA for the administration of these medicinal treatments indicates a reliable category, routinely used with other medicines, which can be used in pregnancy $(94,95)$.

The presence of metastases or advanced tumours is mostly a contraindication for resection. Chemotherapy is preferred for advanced metastatic neoplasias; the purpose is obviously to prolong mother's life until a safe birth. If the age of the foetus is convenient, chemotherapy provides a palliative treatment option for the pregnant patient and also in the postpartum period. In this latter situation, the decision for chemotherapy treatment belongs to the mother, who has to understand the risks for the foetus, and has to take into consideration a series of moral, religious, ethical precepts, etc.

The foetal exposure to chemotherapy and its impact depends on how advanced the pregnancy is. The consequences are more severe at the beginning of pregnancy, due to the alteration of rapidly dividing cells. Congenital malformations are described in the first trimester and development issues in the second trimester. The immediate effects include $(96,97)$ spontaneous abortion, teratogenesis, premature birth, and the late effects may be carcinogenesis, mental retardation, infertility, etc.

Because there is a lack of experience of pregnant patients suffering from insulinoma, the possible treatment plans can be decided and equivalenced through assimilation with data from the general population suffering from PNET and other malignancies.

Antineoplastic drugs with molecular weight $<500$ Dalton are formally contraindicated, the vast majority like alkylating agents - cyclophosphamide, antimetabolites methotrexate, pass through the placental barrier. In their place, platinum salts are recommended (Carboplatin) or antibiotics (Doxorubicin). The usual treatment regimen for PNET uses antimetabolites (for ex. 5-FU) and some alkylating agents (for ex. Streptozotocin), being the most convenient dual formula (98), apparently with the minimal effects on the foetus. Antibiotics or derived Vinca alkaloids do not determine 
foetal side effects; etoposide induces pancytopenia and cisplatin causes hypoacusis or growth retardation. The therapeutic role and side effects of new agents (oxaliplatin, irinotecan, capecitabine) are not well explored or documented. For example, oxaliplatin is classified by the FDA in the toxicity category $\mathrm{D}$, with the risk of foetal lesions (99).

Foetal toxicity depending on monotherapy versus polychemotherapy ascertains a slight increase, from 17 to $25 \%$ in the case of multi-drug chemotherapy (100).

Chemotherapy must not be administrated after week 33 or 3 weeks before birth.

Molecular treatments, like targeted therapy with mTOR pathway inhibitors (for example Everolimus) or antiangiogenic drugs (for instance Sunitinib or other variants), have been used in PNETs with relatively good results (101-104), but up to this moment, there are not enough studies to offer information about side effects on the foetus.

For metastatic cases, the therapeutic possibilities are relatively modest, surgical resection being the first treatment plan followed by TACE (transcatheter arterial chemoembolization), systemic chemotherapy, intratumoral ethanol injection, radiofrequency ablation.

Surgical treatment indeed remains the only therapeutic method, but most often it is scheduled usually after birth, or if the situation requires, as late as possible after the foetus has a convenient age (after 28 weeks). The pregnancy requires an open surgical intervention.

During surgery and the perioperative period, the foetus is exposed to surgical "aggression" - laparotomy, anaesthetic and surgical recovery, transplacental passage of drugs (fluran, barbituric acids, diverse narcotics, etc.). For anaesthesia, numerous guidelines present principles and recommendations to be followed in pregnancy, a high level of knowledge and awareness is mandatory (105).

During surgery, the most critical problems for the foetus are hypoxia and hypotension. An example of problem during surgery is the decrease of placental perfusion having a mechanical cause, as a consequence of a prolonged supine position, especially in advanced pregnancies $(105,106)$.

Post-operatively, a series of problems can arise: infectious conditions associated or not with fever, eating and transit disorders, risk of thrombosis or pulmonary embolism; they can secondary affect the foetus. Anyway, the anxiety of the physician and family towards surgery is most of the times higher than the real risk itself (a rate of abortion of approximately 15\%) (107).

If the diagnosis is obtained in the first half of the pregnancy period (less than 28 weeks), surgical ablation is necessary if the symptomatology is aggressive, hard to control with conservative treatment, when the tumour is identified or if there are solid arguments for malignancy, the long-time until the foetus becomes mature substantially increasing the risk of tumour progression. In this case, depending on the tumour stage, terminating the pregnancy for speeding up the treatment seems to be the desired option. Until 20-30 years ago, the risk of foetal death or abortion was significant in the case of surgical abdominal resections (approx. 25\%). Nowadays, because of the new surgical and anaesthetic techniques and laparoscopic surgery, the risk of foetal demise has decreased to $4 \%$; even the abortion risk has met a drastic decrease, the rate is double compared to the general population (108-113). Neither the risk of malformations is different from the general population; however, there is a higher level of low birth weight.

After 28 weeks, birth can safely take place in a few weeks, followed by surgical resection after 10-14 days. In this new context, surgery can be performed using minimally-invasive techniques. Once the pregnancy is over, surgery is recommended in all cases. The topographic diagnosis of the lesion is mandatory for a successful surgical treatment. The impossibility of identifying the tumour site before surgery asks for a rigorous examination of the pancreas and peripancreatic area on the operating table added to a US assessment (114-116). 
The macroscopic and ultrasound nature of the lesion decide the surgical technique. The presence of benignity signs opens the way for a limited surgical intervention - enucleation, enucleoresection - the specimen being sent for an extemporaneous HP confirmation. The topography of the insulinoma has a vital role in the decision. A cephalopancreatic site recommends an enucleoresection, whereas a corporeo-caudal position justifies a corporeocaudal pancreatic resection with preservation of the spleen. The advantage of resection is the possibility of en-bloc resection of other tumour sites.

The malignancy confirmation during surgery facilitates radical interventions: cephalic duodenopancreatectomy (DPC), respectively corporeo-caudal splenopancreatectomy (117).

The lack of tumour identification, both before and during surgery, can justify an eventual "blind"corporeo-caudal pancreatic resection, but it can be considered somehow abusive, and it is avoided through the follow-up of the patient and the management of hypoglycaemia crisis using drugs, and performing periodic imaging evaluations.

\section{Conflict of Interest}

The author declare no conflicts of interests.

\section{References}

1. World Health Organization. Ten statistical highlights in global public health. World Health Statistics 2007. Geneva: World Health Organization; 2007.

2. Ferlay J, Shin HR, Bray F, Forman D, Mathers CD, Parkin D. GLOBOCAN 2008, Cancer Incidence and Mortality Worldwide: IARC CancerBase No.10. Lyon, France: International Agency for Research on Cancer. 2010.

3. Center MM, Jemal A, Smith RA, Ward E. Worldwide variations in colorectal cancer. CA Cancer J Clin. 2009;59(6):366-378

4. Center MM, Jemal A, Ward E. International trends in colorectal cancer incidence rates. Cancer Epidemiol Biomarkers Prev. Jun 2009;18(6):1688-1694

5. Altekruse SF, Kosary CL, Krapcho M, Neyman N, \& all. SEER Cancer Statistics Review, 1975-2007, National Cancer Institute. Bethesda, based on November 2009 SEER data submission, posted to the SEER web site, 2010.

6. Conroy T, Desseigne F, Ychou M, Bouché O, Guimbaud R, Bécouarn Y, et al. FOLFIRINOX versus gemcitabine for metastatic pancreatic cancer. N Engl J Med. 2011;364(19):1817-25.

7. Massironi S, Sciola V, Peracchi M, Ciafardini C, Spampatti MP, Conte D. Neuroendocrine tumors of the gastro-entero-pancreatic system. World J Gastroenterol. 2008; 14(35):5377-84.
8. Metz DC, Jensen RT. Gastrointestinal neuroendocrine tumors: pancreatic endocrine tumors. Gastroenterology. 2008;135(5): 1469-92.

9. Klöppel G, Anlauf M. Epidemiology, tumour biology and histo-pathological classification of neuroendocrine tumours of the tract. Best Pract Res Clin Gastroenterol. 2005;19(4):507-17.

10. Besemer B, Müssig K. Insulinoma in pregnancy. Exp Clin Endocrinol Diabetes. 2010;118:9-18.

11. Oberg K, Eriksson B. Endocrine tumours of the pancreas. Best Pract Res Clin Gastroenterol. 2005;19:753-781.

12. Falconi M, Plockinger U, Kwekkeboom DJ, Manfredi R, Korner M, Kvols $\mathrm{L}$, et al. Well-differentiated pancreatic nonfunctioning tumors/ carcinoma. Neuroendocrinology. 2006;84(3):196-211.

13. O'Toole D, Salazar R, Falconi M, Kaltsas G, Couvelard A, de Herder WW, et al. Rare functioning pancreatic endocrine tumors. Neuroendocrinology. 2006;84(3):189-95. Epub 2007 Feb 20.

14. Jensen RT, Berna MJ, Bingham DB, Norton JA. Inherited pancreatic endocrine tumor syndromes: advances in molecular pathogenesis, diagnosis, management, and controversies. Cancer. 2008;113(7 Suppl):1807-43.

15. Service FJ, McMahon MM, O'Brien PC, Ballard DJ. Functioning insulinomas-incidence. Recurrent and long-term survival of patients: a 60 year study. Mayo Clin Proc. 1991;66(7):711-9.

16. Gibril F, Schumann M, Pace A, Jensen RT. Multiple endocrine neoplasia type 1 and Zollinger-Ellison syndrome: a prospective study of 107 cases and comparison with 1009 cases from the literature. Medicine (Baltimore). 2004;83(1):43-83.

17. Christiansen $\mathrm{E}$, Vestergaard $\mathrm{H}$. Insulinoma in a third-trimester pregnant woman combined with pre-eclampsia: a case report and review of the diagnostic strategies .Gynecol Endocrinol. 2008; 24(7):417-22.

18. Dadan J, Wojskowicz P, Wojskowicz A. Neuroendocrine tumors of the pancreas. WiadLek. 2008:61(1-3):43-7.

19. Constantinoiu S, Constantin A, Predescu D, Iosif C, Hoara P, Achim F, et al. Somatostatinoma of the first jejunal loop in a patient with neurofibromatosis Von Recklinghausen and bilateral pheochromocytoma. Hepatogastroenterology. 2012;59(118):1874-8.

20. Norton JA, Kivlen M, Li M, Schneider D, Chuter T, Jensen RT. Morbidity and mortality of aggressive resection in patients with advanced neuroendocrine tumors. Arch Surg. 2003;138(8):859-66.

21. Juvara I, Dragomirescu C. Insulinoamele în cancerul și alte tumori ale sistemului endocrin. Chiricuță I. (ed). Colecția Enciclopedia Oncologică (Cluj-Napoca). 1984;14:262-83.

22. Pătrașcu Tr, Doran H, Belușică L, Prunaiche M, Goanță A, Vereanu I. Organic hypoglycemia of pancreatic cause. Chirurgia (Bucur). 2003;98(6):509-14. Romanian

23. Popovici A, Petca A, Grigoroiu M, Nica A. Insulinomas-nesidioblastomas. Clinical experience. Chirurgia (Bucur). 1997; 92(6):387-97. Romanian

24. Ticmeanu F, Simion S, Croitoru A, Mastalier B, Angelescu M, Seicaru T. Insulinoamele pancreatice. Chirurgia (Bucur). 2001; 96(3):227-80.

25. Târcoveanu E, Lupașcu C, Moldovanu R, Dimofte G, Epure 0, Mogoș $\mathrm{V}$, et al. Insulinoamele pancreatice Jurnalul de Chirurgie (lasi). 2005:1(1):42-52

26. Jensen TR, Norton AJ. Pancreatic endocrine tumors. In Sleisenger and Fordtran's Gastrointestinal and Liver disease, 7-th edition, Saunders Elsevier Science. 2002. p. 988-1016.

27. Pospai D. Tumorile pancreasului endocrin. In: Tratat de hepato-gastroenterologie, vol. 2, Buligescu L (ed). București: Ed. Medicală Amaltea; 1999. p. 971-987.

28. Rodrigues Queiróz AJ, Nazareno LS, Miranda JE, de Azevedo AE, Teixeira da Cruz CA, Pirani Carneiro F, et al. Insulinoma diagnosed in the postpartum: clinical and immunohistochemical features. Gynecol Endocrinol. 2012;28(8):633-6.

29. Takacs CA, Krivak TC, Napolitano PG. Insulinoma in pregnancy: a case report and reviewof the literature. Obstet Gynecol Surv. 2002; 57(4):229-35.

30. Müssig K, Wehrmann M, Horger M. Insulinoma and pregnancy. Fertil Steril. 2009;91(2):656. Epub 2008 Dec 25. Comment on Insulinoma associated with pregnancy. [Fertil Steril. 2008] 
31. Barbour LA, Shao J, Qiao L, Pulawa LK, Jensen DR, Bartke A, et al. Human placental growth hormone increases expression of the p85 regulatory unit of phosphatidylinositol 3-kinase and triggers severe insulin resistance in skeletal muscle. Endocrinology. 2004;145(3): 1144-50. Epub 2003 Nov 21.

32. Kirwan JP, Hauguel-De Mouzon S, Lepercq J, Challier JC, HustonPresley L, Friedman JE, et al. TNF-a is a predictor of insulin resistance in human pregnancy. Diabetes 2002;51:2207-13.

33. Service FJ. Hypoglycemic disorders. N Engl J Med. 1995 332(17):1144-52.

34. Queiroz Almeida M, Machado MC, Correa-Giannella ML, GiannellaNeto D, Albergaria Pereira MA. Endogenous hyperinsulinemic hypoglycemia: diagnostic strategies, predictive features of malignancy and long-term survival. J Endocrinol Invest. 2006; 29(8):679-87.

35. Starke A, Saddig C, Mansfeld L, Koester R, Tschahargane C, Czygan P, et al. Malignant metastatic insulinoma-postoperative treatment and follow-up. World J Surg. 2005;29(6):789-93.

36. Anderson MA, Carpenter S, Thompson NW, Nostrant TT, Elta GH, Scheiman JM. Endoscopic ultrasound is highly accurate and directs management in patients with neuroendocrine tumors of the pancreas. Am J Gastroenterol. 2000;95(9):2271-7.

37. Gouya H, Vignaux 0, Augui J, Dousset B, Palazzo L, Louvel A, et al. CT, endoscopic sonography, and a combined protocol for preoperative evaluation of pancreatic insulinomas. AJR Am J Roentgenol. 2003;181:987-992.

38. Ardengh JC, Rosenbaum P, Ganc AJ, Goldenberg A, Lobo EJ, Malheiros CA, et al. Role of EUS in the preoperative localization of insulinomas compared with spiral CT. Gastrointest Endosc. 2000:51(5):552-5.

39. Linda S. Lee Diagnosis of Pancreatic Neuroendocrine Tumors and the Role of Endoscopic Ultrasound Gastroenterol Hepatol (N Y). 2010;6(8):520-522

40. Klapman JB, Logrono R, Dye CE, Waxman I. Clinical impact of on-site cytopathology interpretation on endoscopic ultrasound-guided fine needle aspiration. Am J Gastroenterol. 2003;98:1289-1294.

41. ASGE Standard of Practice Committee, Shergill AK, Ben-Menachem T, Chandrasekhara V, Chathadi K, Decker GA, et al. Guidelines for endoscopy in pregnant and lactating women. Gastrointest Endosc. 2012;76(1):18-24. Erratum in Gastrointest Endosc. 2013;77(5):833.

42. Hsu JJ, Clark-Glena R, Nelson DK, Kim CH. Nasogastric enteral feeding in the management of hyperemesis gravidarum. Obstet Gynecol. 1996;88(3):343-6.

43. Cappell MS, Colon VJ, Sidhom OA. A study of eight medica centers of the safety and clinical efficacy of esophagogastroduodenoscopy in 83 pregnant females with follow-up of fetal in 83 pregnant females with follow-up of fetal outcome and with comparison control groups. Am J Gastroenterol. 1996;91(2):348-54.

44. Debby A, Golan A, Sadan O, Glezerman M, Shirin H. Clinical utility of esophagogastroduodenoscopy in the management of recurrent and intractable vomiting in pregnancy. J Reprod Med. 2008; 53(5):347-51.

45. Frank B. Endoscopy in pregnancy. In: Karlstadt RG, Surawicz CM, Croitoru R, editors, Gastrointestinal disorders during pregnancy. Arlington,VA: American College of Gastroenterology, 1994: 24-29

46. Sundin A, Vullierme MP, Kaltsas G, Plöckinger U, Mallorca Consensus Conference participants., European Neuroendocrine Tumor Society. ENETS Consensus Guidelines for the Standards of Care in Neuroendocrine Tumors: radiological examinations. Neuroendocrinology. 2009;90(2):167-83.

47. Tamm EP, Kim EE, Ng CS. Imaging of neuroendocrine tumors. Hematol Oncol Clin North Am. 2007 Jun;21(3):409-32; vii.

48. Streffer C, Shore R, Konermann G, Meadows A, Uma Devi P, Preston Withers $J$, et al. Biological effects after prenatal irradiation (embryo and fetus). A report of the International Commission on Radiological Protection. Ann ICRP. 2003:33(1-2):5-206.

49. Wagner LK, Lester RG, Saldana LR. Exposure of the pregnant patient to diagnostic radiations: a guide to medical management. Philadelphia; Lippincott 1985; 19-223.

50. Berlin L. Radiation exposure and the pregnant patient. AJR Am J
Roentgenol. 1996;167(6):1377-9

51. Damilakis J, Prassopoulos P, Perisinakis K, Faflia C, Gourtsoyiannis N. CT of the sacroiliac joints: Dosimetry and optimal settings for a highresolution technique. Acta Radiol. 1997;38(5):870-5.

52. Damilakis J, Perisinakis K, Voloudaki A, Gourtsoyiannis N. Estimation of fetal radiation dose from computed tomography scanning in late pregnancy: depth-dose data from routine examinations. Invest Radiol. 2000;35(9):527-33.

53. Goldberg-Stein S, Liu B, Hahn PF, Lee SI. Body CT during pregnancy: utilization trends, examination indications, and fetal radiation doses. AJR Am J Roentgenol. 2011:196(1):146-51.

54. Ratnapalan S, Bona N, Chandra K, Koran G. Physicians' perceptions of teratogenic risk associated with radiography and CT during early pregnancy. AJR Am J Roentgenol. 2004;182(5):1107-9.

55. Bentur $Y$. Ionizing and nonionizing radiation in pregnancy. In: Koren G, ed. Maternal-fetal toxicology: a clinician's guide, 3rd ed. New York, NY: Marcel Dekker; 2001. p. 603-651.

56. Mole RH. Irradiation of the embryo and fetus. Br J Radiol. 1987; 60(709):17-31.

57. Doll R, Wakeford R. Risk of childhood cancer from fetal irradiation. $\mathrm{Br}$ J Radiol. 1997;70:130-9.

58. Gilman EA, Kneale GW, Knox EG, Stewart AM. Pregnancy X-rays and childhood cancers: effects of exposure age and radiation dose. J Radiol Prot. 1988;8:3-8.

59. ACOG Committee on Obstetric Practice. ACOG Committee Opinion. Number 299, September 2004. Guidelines for diagnostic imaging during pregnancy. Obstet Gynecol. 2004;104(3):647-51.

60. Goldberg-Stein SA, Liu B, Hahn PF, Lee SI. Radiation dose management: part 2, estimating fetal radiation risk from CT during pregnancy. AJR, 2012; 198:W352-W356.

61. Morisetti A, Tirone P, Luzzani F, de Haen C. Toxicologic safety assessment of iomeprol, a new x-ray contrast agent. Eur J Radiol 1994; 18 (Suppl 1): 21-31.

62. Ralston WH, Robbins MS, James P. Reproductive, developmental, and genetic toxicity of ioversol. Invest Radiol 1989; 24 (Suppl 1): 16-22.

63. Rodesch F, Camus M, Ermans AM, Dodion J, Delange F. Adverse effects of amniofetography on fetal thyroid function. Am J Obstet Gynecol. 1976;126(6):723-6.

64. Bona G, Zaffaroni M, Defilippi C, Gallina MR, Mostert M. Effects of iopamidol on neonatal thyroid function. Eur J Radiol. 1992; 14(1):225.

65. Atwell TD, Lteif AN, Brown DL, McCann M, Townsend JE, Leroy AJ. et al. Neonatal thyroid function after administration of IV iodinated contrast agent to 21 pregnant patients. AJR Am J Roentgenol. 2008;191(1):268-71

66. Webb JA, Thomsen HS, Morcos SK; Members of Contrast Media Safety. The use of iodinated and gadolinium contrast media during pregnancy and lactation. Eur Radiol. 2005;15(6):1234-40. Epub 2004 Dec 18.

67. Tamm EP, Bhosale P, Lee JH, Rohren EM. State-of-the-art Imaging of Pancreatic Neuroendocrine Tumors. Surg Oncol Clin N Am. 2016;25(2):375-400

68. Heinrichs WL, Fong P, Flannery M, Heinrichs SC, Crooks LE, Spindle $A$, et al. Midgestational exposure of pregnant balb/c mice to magnetic resonance imaging. Mag Res Imag 1986;8:65-69.

69. Tyndall DA, Sulik KK. Effects of magnetic resonance imaging on eye development in the C57BL/6J mouse. Teratology 1991; 43:263275.

70. Yip YP, Capriotti C, Talagala SL, Yip JW. Effects of MR exposure at 1.5T on early embryonic development of the chick. JMRI 1994:4: 742-748.

71. National Radiological Protection Board. Principles for the Protection of Patients and Volunteers During Clinical Magnetic Resonance Diagnostic Procedures. Documents of the NRPB, Volume 2, no 1. London: HM Stationery Office, 1991.

72. Baker PN, Johnson IR, Harvey PR, Gowland PA, Mansfield P. A threeyear follow-up of children imaged in utero with echo-planar magnetic resonance. Am J Obstet Gynecol. 1994:170(1 Pt 1):32-3.

73. Gover P, Hykin J, Gowland P, Wright J, Johnson I, Mansfield P. An assessment of the intrauterine sound intensity level during 
obstetric echo-planar magnetic resonance imaging. $\mathrm{Br} \mathrm{J}$ Radiol. 1995;68(814):1090-4.

74. Marcos HB, Semelka RC, Worawattanakul S. Normal placenta: gadolinium-enhanced dynamic MR imaging. Radiology. 1997;205: 493-6.

75. Spencer JA, Tomlinson AJ, Weston MJ, Lloyd SN. Early report: comparison of breath-hold MR excretory urography, Doppler ultrasound and isotope renography in evaluation of symptomatic hydronephrosis in pregnancy. Clin Radiol. 2000;55:446-53.

76. Shellock FG, Kanal E. Policies, guidelines, and recommendations for MR imaging safety and patient management. JMRI. 1991; 1:97-101.

77. Sundin A, Garske U, Orlefors H. Nuclear imaging of neuroendocrine tumours. Best Pract Res Clin Endocrinol Metab. 2007;21:69-85.

78. Zanotti-Fregonara P, Jan S, Taieb D, Cammilleri S, Trébossen R, Hindié $\mathrm{E}$, et al. Absorbed 18F-FDG dose to the fetus during early pregnancy. J Nucl Med. 2010;51(5):803-5.

79. Takalkar AM, Khandelwal A, Lokitz S, Lilien DL, Stabin MG. 18F-FDG PET in pregnancy and fetal radiation dose estimates. J Nucl Med. 2011; 52(7):1035-40.

80. Hsieh TC, Wu YC, Sun SS, Chu LY, Yen KY, Kao CH. FDG PET/CT of a late-term pregnant woman with breast cancer. Clin Nucl Med. 2012;37(5):489-91.

81. Edge SB, Byrd DR, Compton CC, Fritz AG, Greene FL, Trotti A. AJCC cancer staging manual (7th ed). New York, NY: Springer; 2010.

82. Rindi G1, Klöppel G, Alhman H, Caplin M, Couvelard A, de Herder WW, et al. TNM staging of foregut (neuro) endocrine tumors: a consensus proposal including a grading system. Virchows Arch. 2006;449(4): 395-401.

83. Fischer L, Kleeff J, Esposito I, Hinz U, Zimmermann A, Friess H, et al. Clinical outcome and long-term survival in 118 consecutive patients with neuroendocrine tumours of the pancreas. $\mathrm{Br} \mathrm{J}$ Surg. 2008;95(5):627-35.

84. Pape UF, Jann H, Müller-Nordhorn J, Bockelbrink A, Berndt U, Willich SN, et al. Prognostic relevance of a novel TNM classification system for upper gastroenteropancreatic neuroendocrine tumors. Cancer. 2008;113(2):256-65.

85. La Rosa S, Klersy C, Uccella S, Dainese L, Albarello L, Sonzogni A, et al. Improved histologic and clinicopathologic criteria for prognostic evaluation of pancreatic endocrine tumors. Hum Pathol. 2009;40(1):30-40.

86. Scarpa A, Mantovani W, Capelli P, Beghelli S, Boninsegna L, Bettini R, et al. Pancreatic endocrine tumors: improved TNM staging and histopathological grading permit a clinically efficient prognostic stratification of patients. Mod Pathol. 2010;23(6):824-33.

87. Strosberg JR, Cheema A, Weber J, Han G, Coppola D, Kvols LK. Prognostic validity of a novel American Joint Committee on Cancer staging classification for pancreatic neuroendocrine tumors. J Clin Oncol. 2011;29(22):3044-9.

88. Qadan M, Ma Y, Visser BC1, Kunz PL, Fisher GA, Norton JA, et al. Reassessment of the current American Joint Committee on Cancer staging system for pancreatic neuroendocrine tumors. J Am Coll Surg. 2014;218(2):188-95.

89. Amin MB, Edge S, Greene F, Byrd DR, Brookland RK, Washington MK, Gershenwald JE, Compton CC, Hess KR, et al. (Eds.). AJCC Cancer Staging Manual (8th edition). Springer International Publishing: American Joint Commission on Cancer; 2017.

90. Peiper H. PankretischeApudome. Chirurg 51:380, 1988

91. Lepage C, Ciccolallo L, De Angelis R, Bouvier AM, Faivre J, Gatta G; EUROCARE working group. Europeandisparities in malignant digestive endocrine tumourssurvival. Int J Cancer. 2010;126(12): 2928-34.

92. Whitemann VE, Homko CJ, Reece EA. Management of hypoglycemia and diabetic ketoacidosis in pregnancy. Obst Gynecol Clin North Am. 1996;23:87-107.

93. Braga AFA, Braga FSDS, Junior JHZ, Brandăo MJN, Marcondes GA, Barbosa TDA. Insulinoma and pregnancy: anesthesia and perioperative management. Rev Bras Anestesiol. 2017;67(4):426-429.
94. Besemer B, Müssig K. Insulinoma in pregnancy. Exp ClinEndocrinol Diabetes. 2010;118:9-18.7

95. Freemark M. Ontogenesis of prolactin receptors in thehumanfetus: roles in fetal development. Biochem Soc Trans.2001;29:38-41

96. Leslie KK, Koil C, Rayburn WF. Chemotherapeutic drugs in pregnancy. Obstet Gynecol Clin North Am. 2005;32:627-640.

97. Beeley L. Adverse effects of drugs in the first trimester of pregnancy. Clin ObstetGynaecol. 1986;13:177-19.

98. Delaunoit T, Ducreux M, Boige V, Dromain C, Sabourin JC, Duvillard P, et al. The doxorubicin-streptozotocin combination for the treatment of advanced well-differentiated pancreatic endocrine carcinoma; a judicious option? Eur J Cancer. 2004;40(4):515-20.

99. Minter A, Malik R, Ledbetter L, Winokur TS, Hawn MT, Saif MW. Colon cancer in pregnancy.. Cancer Control. 2005;12(3):196-202.

100. Doll DC, Ringenberg QS, Yarbro JW. Antineoplastic agents and pregnancy. Semin Oncol 1989;16:337-346.

101. Duran I, Kortmansky J, Singh D, Hirte H, Kocha W, Goss G, et al. A phase II clinical and pharmacodynamic study of temsirolimus in advanced neuroendocrine carcinomas. Br J Cancer. 2006;95(9): 1148-54.

102. Pavel ME, Baudin 2, Öberg KE, Hainsworth JD, Voi M, Rouyrre N, Peeters M, Gross DJ, Yao JC. Efficacy of everolimus plus octreotide LAR in patients with advanced neuroendocrine tumor and carcinoid syndrome: final overall survival from the randomized, placebocontrolled phase 3 RADIANT-2 study. Ann Oncol. 2017;28(7): 1569-1575.

103. Yao JC, Phan AT, Chang DZ, Wolff RA, Hess K, Gupta S, et al. Efficacy of RAD001 (everolimus) and octreotide LAR in advanced low- to intermediate-grade neuroendocrine tumors: results of a phase II study. $J$ Clin Oncol. 2008;26(26):4311-8.

104. Kulke MH, Lenz HJ, Meropol NJ, Posey J, Ryan DP, Picus J, et al. Activity of sunitinib in patients with advanced neuroendocrine tumors. J Clin Oncol. 2008;26(20):3403-10.

105. Morris MC. Obstetric anaesthesia. Philadelphia: JB Lippincott Co. 1993.

106. Leighton BL. Anaesthetic complications. In: Norris MC, ed. Obstetric anaesthesia. Philadelphia: JB Lippincott Co; 1993. p. 616-18.

107. Doll DC, Ringenberg QS, Yarbro JW. Management of cancer during pregnancy. Arch Intern Med. 1988;148:2058-64.

108. Saunders P, Milton PJD. Laparotomy during pregnancy: an assessment of diagnostic accuracy and fetal wastage. BMJ. 1993;3: 165-167.

109. Skilling JS. Colorectal cancer complicating pregnancy. Obstet Gynecol Clin North Am. 1998;25:417-421.

110. Mazze RI, Kallen B. Reproductive outcome after anesthesia and operation during pregnancy: a registry study of 5,405 cases. Am J Obstet Gynecol. 1989;161:1178-1185

111. Curet MJ, Allen D, Josloff RK, Pitcher DE, Curet LB, Miscall BG, et al. Laparoscopy during pregnancy. Arch Surg. 1996;131:546-550; discussion 550-551.

112. Rizzo AG. Laparoscopic surgery in pregnancy: long-term follow up. J Laparoendosc Adv Surg Tech A. 2003;13:11-15.

113. Lemaire BM, van Erp WR. Laparoscopic surgery during pregnancy. Surg Endosc. 1997;11:15-18.

114. lihara M, Kanbe M, Okamoto T, ItoY, Obara T: Laparoscopic ultrasonography for resection of insulinomas. Surgery. 2001;130(6): 1086-91.

115. Tagaya N, Ishikawa K, Kubota K. Spleen-preserving laparoscopic distal pancreatectomy with conservation of the splenic artery and vein for a large insulinoma. Surg Endosc. 2002;16(1):217-8.

116. Wu M, Wang H, Zhang X, Gao I, Liu P, Yu B, et al. Efficacy of laparoscopic ultrasonography in laparoscopic resection of insulinoma. Endosc Ultrasound. 2017;6(3):149-155.

117. Kianmanesh R O'toole D, Sauvanet A, Ruszniewski P, Belghiti J. Surgical treatment of gastric, enteric, and pancreatic endocrine tumors. Treatment of primary endocrine tumors. J Chir ( Paris). 2005;142(3):132-49. 